DOI: https://doi.org/10.32838/2523-4803/71-3-12

удК 334.012:338.48

\title{
Цвілий С.М.
}

кандидат економічних наук, доцент,

Національний університет «Запорізька політехніка»

Корніснко О.М.

кандидат економічних наук, доцент,

Національний університет «Запорізька політехніка»

Tsviliy Sergiy, Korniienko Olga

National University «Zaporizhzhia Polytechnic»

\section{ПОСТКОРОНАВІРУСНЕ ВІДНОВЛЕННЯ БІЗНЕС-АКТИВНОСТІ МІКРОПІДПРИЕМСТВ СФЕРИ ГОСТИННОСТІ РЕГІОНУ}

\begin{abstract}
У статті розглянуто перспективи посткоронавірусного відновлення бізнес-активності вітчизняних мікрокомпаній сфери гостинності регіону. Виокремлено низку чинників, які здійснюють негативний вплив на мікробізнес регіональної сфери гостинності. Проведено аналіз досвіду функціонування мікропідприємств регіону в умовах дії факторів COVID-19. Представлено структуру мікропідприємництва Запорізької області за видами економічної діяльності та проведено ї̈ аналіз за 2015-2019 рр. Зроблено групування мікропідприємств щиодо їх інтегрованості у сферу гостинності регіону на базі поділу за видами економічної діяльності. Розроблено дієві рекомендації з вибору вектору посткоронавірусного відновлення бізнес-активності вітчизняних компаній мікробізнесу регіону, який передбачає інноваційний розвиток на засадах застосування сучасного клієнтоорієнтованого niдходу.
\end{abstract}

Ключові слова: бізнес, гостинність, компанія, інновація, регіон.

Постановка проблеми. В умовах дії факторів COVID-19 загострилося багато питань 3 організації бізнесу мікропідприємств сфери гостинності, які до цього були у статусі перспективних і сприймалися керівництвом компаній даного типу досить інертно [6]. До цих питань віднесено: асортимент і якість продукту, додаткові послуги для гостей, конкурентоспроможність компанії, безпека споживачів, партнерські відносини, екологічність бізнесу, участь у цільових програмах, пільгове оподаткування тощо. Зрозуміло, що сьогодні глобальна та вітчизняна туристична сфера (у тому числі регіональна сфера гостинності) зазнає збитків унаслідок заходів протидії пандемії COVID-19. Водночас поточну кризову ситуацію слід розглядати не лише як проблеми, а й як можливості виведення сфери гостинності регіонів України на новий рівень розвитку. Стан регіональної сфери гостинності та суміжних галузей і сфер бізнесу потребує перегляду й адаптації до умов циркулярної економіки. Базою переходу до структури регіональної економіки нового типу є відновлення бізнес-активності мікропідприємств галузі на таких засадах, як: посткоронавірусне підвищення ролі підприємств мікробізнесу в розвитку територій, дестинацій, регіонів; упровадження сучасник практик та світового досвіду в управлінні бізнесом компаній; реалізація інструментарію державно-приватного партнерства; активізація інноваційно-інвестиційних механізмів на регіональ- ному рівні; діджитилізація бізнес-процесів у підприємництві. Саме тому вибраний напрям дослідження $є$ актуальним та своєчасним.

Аналіз останніх досліджень і публікацій. Вивченню сучасного стану та розвитку туристичної індустрії присвятили роботи вітчизняні й закордонні вчені, а саме: Г. Горбань, В. Герасименко, Л. Воротіна, Л. Дяченко, В. Кифяк, І. Кравчук, О. Любіцева, У. Теобальд та ін. Значний внесок у розвиток галузі гостинності зробили такі вчені, як: В. Азар, Дж. Боуен, А. Віндюк, А. Дурович, Г. Карпова, Д. Мейкенз, А. Рігер, Г. Рогов, Д. Соундерс та ін. Специфічні риси управління мікрокомпаніями сфери гостинності епізодично висвітлено у працях Ю. Алексєєвої, В. Зайцевої, Т. Кукліної, К. Павлюка, Г. Скляра, В. Удовиченко, Р. Харрода й ін. Окремі практичні аспекти бізнесу мікрокомпаній регіону в умовах COVID-19 розглянуто в наукових роботах Д. Василичева, С. Гресь-Свреінової, Д. Гурової, С. Журавльової, Д. Мамотенко та інших відомих учених [3; 7; 8]. Однак за наявності значної кількості наукових ідей сьогодні практично відсутні комплексні дослідження, які присвячені формуванню дієвих підходів до визначення шляхів відновлення бізнес-активності мікрокомпаній вітчизняної сфери гостинності в умовах посткоронавірусної економіки регіонів України.

Формулювання цілей статті. Вивчити сучасні реалії сфери гостинності регіону і на основі дослідження досвіду функціонування мікропідприємств в умовах 
дії факторів пандемії COVID-19 розробити дієві рекомендації щодо посткоронавірусного відновлення бізнес-активності компаній даного типу.

Виклад основного матеріалу. Узагальнення вітчизняного і зарубіжного досвіду визначення сутнісних характеристик індустрії гостинності дало змогу констатувати, що вона охоплює форми бізнесу у сфері послуг, які пов'язані з обслуговуванням гостей, а саме: 1) види сервісу, які базуються на принципах гостинності й відтворюють щедрість і дружелюбність стосовно клієнтів; 2) це сукупність суб'єктів мікропідприємництва (туристичні агенції, готелі, мотелі, об'єкти показу тощо), для яких спільність полягає у комплексності фізичних, соціальних, емоційних компонентів продукту; 3) фірми індустрії гостинності (ресторани, готелі, курорти тощо) приймають участь в створенні невидимого продукту, придатного до вживання тільки у момент пропозиції споживачеві. Отже, компанії сфери гостинності справедливо ототожнено 3 мікробізнесом.

В Україні значного негативного впливу COVID-19 зазнали підприємства мікробізнесу сфери гостинності в регіонах, оскільки саме вони є основними продавцями комплексного продукту гостям. Так, практика ïх функціонування за 2020-2021 pp. підтверджує велику кількість претензій відносно порушень прав споживачів і рекламацій від них щодо нікчемності продуктів і випадків відмови від планів організації подорожей з причин дії медичних обмежень. За умов утрати клієнтів, коронавірусних перешкод для бізнесу, відсутності реальної допомоги з боку органів публічної влади регіональні мікрокомпанії зазнали необгрунтованих збитків і змушені були знизити бізнесактивність.
Вивчення стану регіональної сфери гостинності дало змогу виокремити низку чинників, які здійснюють негативний вплив на їі мікробізнес (табл. 1).

Згідно 3 даними табл. 1, сім із десяти чинників $\epsilon$ зовнішніми по відношенню до мікропідприємств; зниження негативного впливу чинників «регіоналізація бізнесу» та «просування продукту» може здійснитися за рахунок реалізації механізму державно-приватного партнерства [5]; «діджиталізація бізнесу» $є$ внутрішнім чинником загрози компанії, який необхідно негайно усунути [4].

Зрозуміло, що відновлення бізнес-активності мікропідприємств сфери гостинності регіону в посткоронавірусній перспективі повинно починатися зі стратегічного аналізу власного потенціалу та розроблення відповідної стратегії з урахуванням оновлених чинників зовнішнього середовища. У табл. 2 подано структуру мікробізнесу Запорізької області за видами економічної діяльності.

За даними табл. 2, структура мікропідприємств за період 2015-2019 pр. не зазнала значних змін. За такого поділу (за видами економічної діяльності) доцільно зробити їх групування щодо інтегрованості у сферу гостинності регіону. Так, до першої групи (висока інтегрованість) має сенс віднести: тимчасове розміщення й організацію харчування; охорону здоров'я та надання соціальної допомоги; мистецтво, спорт, розваги та відпочинок (у 2019 р. загальна їх частка - 4,08\%). До другої групи (середня інтегрованість) слід віднести: оптову та роздрібну торгівлю; ремонт автотранспортних засобів, мотоциклів; транспорт, складське господарство, поштову та кур'єрську діяльність; інформацію та телекомунікації $(34,81 \%)$. До третьої групи (низька інтегрованість) віднесено: сільське, лісове та

Таблиця 1

Чинники негативного впливу на регіональну сферу гостинності

\begin{tabular}{|c|c|}
\hline Чинник & Сутність негативного впливу \\
\hline $\begin{array}{l}\text { Світова еконо- } \\
\text { мічна криза }\end{array}$ & $\begin{array}{l}\text { Криза внаслідок дії факторів COVID-19 та глобальна економічна рецесія, які автоматично відобразилися } \\
\text { на вітчизняній регіональній сфері гостинності України. }\end{array}$ \\
\hline $\begin{array}{l}\text { Військово-полі- } \\
\text { тичний ризик }\end{array}$ & $\begin{array}{l}\text { Високий ступінь невизначеності майбутніх перспектив тимчасово окупованої АР Крим й території } \\
\text { ОРДЛО, що здійснює вплив на безпеку організації подорожей. }\end{array}$ \\
\hline $\begin{array}{l}\text { План } \\
\text { відновлення } \\
\text { та розвитку }\end{array}$ & $\begin{array}{l}\text { Відсутність реальної стратегії відновлення активності бізнесу на рівні держави та її регіонів, чіткого } \\
\text { плану і етапів конкретних економічних заходів підтримки. }\end{array}$ \\
\hline $\begin{array}{l}\text { Стандарти якості } \\
\text { послуг }\end{array}$ & $\begin{array}{l}\text { Невідповідність більшості об’єктів інфраструктури вітчизняної сфери гостинності регіонів міжнародним } \\
\text { стандартам якості обслуговування споживачів. }\end{array}$ \\
\hline $\begin{array}{l}\text { Інвестиційні } \\
\text { процеси }\end{array}$ & $\begin{array}{l}\text { Інертність процесів щодо інвестування у відновлення та розвиток матеріальної бази туристичних об’єктів } \\
\text { й розвиток транспортної мережі та логістики регіонів. }\end{array}$ \\
\hline $\begin{array}{l}\text { Інноваційна } \\
\text { діяльність }\end{array}$ & $\begin{array}{l}\text { Недостатність дослідницького, дослідного, наукового забезпечення галузі; низький техніко-технологіч- } \\
\text { ний рівень сервісних засобів для обслуговування гостей. }\end{array}$ \\
\hline $\begin{array}{l}\text { Політика } \\
\text { протекціонізму }\end{array}$ & $\begin{array}{l}\text { Відсутність сучасних дієвих механізмів забезпечення преференцій бізнесу на рівні мікропідприємств } \\
\text { регіону щодо підвищення рівня їхньої конкурентоспроможності. }\end{array}$ \\
\hline $\begin{array}{l}\text { Регіоналізація } \\
\text { бізнесу }\end{array}$ & $\begin{array}{l}\text { Недостатня розвиненість структури організації бізнес-процесів та партнерства в середовищі підприємни- } \\
\text { цтва на рівні локацій, дестинацій, областей, регіонів. }\end{array}$ \\
\hline $\begin{array}{l}\text { Просування } \\
\text { продукту }\end{array}$ & $\begin{array}{l}\text { Відсутність єдиної політики просування комплексного продукту мікропідприємств сфери гостинності } \\
\text { регіону на внутрішньому і міжнародному туристичних ринках. }\end{array}$ \\
\hline $\begin{array}{l}\text { Діджиталізація } \\
\text { бізнесу }\end{array}$ & $\begin{array}{l}\text { Низький рівень використання digital-технологій для модернізації процесу розроблення комплексного } \\
\text { продукту й обслуговування закордонних та вітчизняних туристів. }\end{array}$ \\
\hline
\end{tabular}


Питома вага мікропідприємств Запорізької області за видами економічної діяльності у 2015-2019 рр., \% до їх загальної кількості

\begin{tabular}{|c|c|c|c|c|c|}
\hline Види діяльності / роки & 2015 & 2016 & 2017 & 2018 & 2019 \\
\hline Усього & 100 & 100 & 100 & 100 & 100 \\
\hline сільське, лісове та рибне господарство & 18,71 & 19,97 & 20,18 & 19,39 & 18,43 \\
\hline промисловість & 10,44 & 10,61 & 10,75 & 11,25 & 11,69 \\
\hline будівництво & 7,58 & 7,13 & 7,09 & 7,18 & 7,31 \\
\hline оптова та роздрібна торгівля; ремонт автотранспортних засобів і мотоциклів & 29,43 & 29,03 & 28,44 & 27,99 & 28,04 \\
\hline транспорт, складське господарство, поштова та кур’єрська діяльність & 3,35 & 3,15 & 3,20 & 3,32 & 3,48 \\
\hline тимчасове розміщування й організація харчування & 2,41 & 2,21 & 2,34 & 2,38 & 2,43 \\
\hline інформація та телекомунікації & 2,86 & 2,95 & 2,87 & 3,08 & 3,29 \\
\hline фінансова та страхова діяльність & 0,57 & 0,63 & 0,51 & 0,46 & 0,43 \\
\hline операції з нерухомим майном & 10,96 & 11,55 & 11,88 & 11,99 & 12,00 \\
\hline професійна, наукова та технічна діяльність & 7,20 & 6,60 & 6,34 & 6,31 & 6,11 \\
\hline діяльність у сфері адміністративного та допоміжного обслуговування & 3,21 & 3,04 & 3,32 & 3,49 & 3,57 \\
\hline освіта & 0,47 & 0,46 & 0,45 & 0,49 & 0,56 \\
\hline охорона здоров'я та надання соціальної допомоги & 1,22 & 1,16 & 1,14 & 1,28 & 1,18 \\
\hline мистецтво, спорт, розваги та відпочинок & 0,48 & 0,45 & 0,46 & 0,43 & 0,47 \\
\hline надання інших видів послуг & 1,10 & 1,06 & 1,03 & 1,03 & 1,00 \\
\hline
\end{tabular}

Джерело: [1]

рибне господарство; фінансову та страхову діяльність; операції з нерухомим майном (30,86\%). Тобто 69,75\% мікропідприємств регіону прямо чи опосередковано потребують відновлення бізнес-активності.

Досліджено думку власників 50 мікропідприємств iз високим ступенем інтегрованості у сферу гостинності Запорізької області відносно перспектив швидкого відновлення бізнес-активності (було заповнено google-форму) та на основі їхніх відповідей складено фрагмент матриці SWOT-аналізу (табл. 3).

Також, на думку власників указаної кількості мікропідприємств регіону, відновлення активності бізнесу цілком залежить від реалізації внутрішнього потенціалу компаній. Із цієї позиції для компаній розроблено рекомендації з вибору вектору посткоронавірусного відновлення бізнес-активності, який передбачає інноваційний розвиток на засадах клієнтоорієнтованого підходу. Під інноваційним розвитком мікропідприємства сфери гостинності в умовах посткоронавірусного стану зовнішнього середовища слід розуміти траєкторію його руху, за якою забезпечується зовнішня ефективність функціонування за допомогою реалізації системи змін різних форм, котрі зумовлені комбінацією факторів, а саме: 1) нові технології; 2) їх застосування у формі нових послуг, продуктів і процесів; 3) нові ринки або окремі сегменти; 4) нові організаційні структури управління, організаційний дизайн; 5) нові підходи до управління. Зміни впроваджуються паралельно-послідовно й $є$ продуктом системи знань.

Своєю чергою, клієнтоорієнтований підхід до управління інноваційним розвитком у процесі відновлення бізнес-активності мікрофірми передбачає:

- надання унікальної послуги: кінцевий продукт диференційований, унікальний у своєму роді, що приносить споживачеві додаткові переваги;
- забезпечення глобальної концепції продукту: ідея, задум і розроблення товару і послуги спочатку повинні орієнтуватися на світові стандарти якості;

- забезпечення маркетингової орієнтації досліджуваних процесів;

- проведення інтенсивного первинного аналізу: до початку розроблення повинні витрачатися ресурси на поглиблене обгрунтування прогнозних змін;

- реалізація стратегії нового продукту: план дій здійснення проєкту, перелік завдань, вибір ринку, набір властивостей його позиціонування;

- ставлення до інформації як до ресурсу, що не обмежується бар'єрами, та на основі створення загальної інформаційної платформи для забезпечення узгодження дій індивідуумів із результатами діяльності мікропідприємства;

- забезпечення міжфункціональної сінергії в межах єдиної філософії компанії відносно нового продукту на базі організації інформаційної мережі за вектором «дослідження - виробництво - маркетинг фінанси - персонал»;

- забезпечення єдності процесів оновлення архіву та моделей знань 3 іншими функціональними бізнеспроцесами та процесами адміністрування;

- управління на основі структурованого плану освоєння нововведень: перехід від планового позиціонування продукту у свідомості споживача до плану операційного маркетингу в часі, цінах, каналах збуту, комунікаціях;

- підтримка ідей та інновацій менеджментом мікропідприємства сфери гостинності (відмова від прямого втручання й зацікавлена підтримка);

- забезпечення економічної, технологічної, споживчої, іміджевої віддачі нововведень (з'єднання всіх для отримання комбінованого ефекту) [2];

- розроблення механізму попереднього відбору інноваційних проєктів; 
Фрагмент матриці SWOT-аналізу

(дослідження перспектив посткоронавірусного відновлення бізнес-активності мікропідприємств)

\begin{tabular}{|c|c|}
\hline & \\
\hline $\begin{array}{l}\text { 1. Готовність компаній до обслуговування гостей на більш } \\
\text { високому рівні якості. } \\
\text { 2. Відповідність вимогам МОЗ України щодо медико-санітар- } \\
\text { ної безпеки закладів. } \\
\text { 3. Велика кількість операторів із надання послуг гостинності } \\
\text { на території області. } \\
\text { 4. Мобільність і гнучкість у пристосуванні до мінливих вимог } \\
\text { ринку та споживачів. } \\
\text { 5. Легкість в управлінні та контролі процесів завдяки опти- } \\
\text { мальним розмірам компанії. }\end{array}$ & $\begin{array}{l}\text { ифровізації мікробізнесу та відсутність } \\
\text { рми. } \\
\text { на створені продукти, послуги, сервіси } \\
\text { нку. } \\
\text { ість оборотних коштів стримує швидке } \\
\text { иток. } \\
\text { тості бренду порівняно із середніми та } \\
\text { твами. } \\
\text { бці значного обсягу оперативної марке- }\end{array}$ \\
\hline Можли & \\
\hline $\begin{array}{l}\text { на транспортна мережа області й відновлений } \\
\text { ого транспорту. } \\
\text { ня інтересу вітчизняних туристів до організації } \\
\text { подорожей. } \\
\text { ввічливе, лояльне, дружелюбне відношення до } \\
\text { уристів. } \\
\text { я активності щодо створення інформаційно-кон- } \\
\text { Іх хабів. } \\
\text { о орієнтири розвитку (Стратегія розвитку туризму } \\
27 \text { рр.) }\end{array}$ & $\begin{array}{l}\text { 1. Відсутність єдиної філософії в регіоні щодо презентації } \\
\text { культурної спадщини. } \\
\text { 2. Сезонність попиту на літній відпочинок та слабкі альтер- } \\
\text { нативні пропозиції. } \\
\text { 3. Висока конкуренція з боку вітчизняних сфер гостинності } \\
\text { інших областей та міст. } \\
\text { 4. Низький рівень економічної, фінансово-юридичної та без- } \\
\text { пеки підприємництва. } \\
\text { 5. Велика кількість об'єктів туристичної інфраструктури } \\
\text { потребує модернізації. }\end{array}$ \\
\hline
\end{tabular}

- контроль над ходом розроблення та реалізації інноваційного проєкту, а також своєчасна відмова від проєкту за зміни ситуативних чинників;

- забезпечення доступу до ресурсів: для успіху слід сформувати кадрові і фінансові ресурси для розгляду як інвестиції, а не як витрат;

- урахування фактору часу як пріоритету у конкурентоспроможності бізнесу: швидкий прихід на ринок 3 якісною пропозицією продукту клієнту;

- реалізація багатоступеневої процедури оцінки майбутніх інновацій.

Слід урахувати, що в процесі оперативного менеджменту неприпустимо поєднувати принципи різних підходів до управління інноваціями компанії та орієнтуватися на довгострокове планування і стратегічне управління ними. Філософію посткоронавірусного бізнесу, який має на меті забезпечення якості стійкого споживання послуг, слід зорієнтувати виключно на інноваційність організаційно-економічної системи мікропідприємства. Посткоронавірусні принципи менеджменту у конкретній компанії повинні бути чітко визначені й утілені керівництвом у процедурах, регламентах, організаційному дизайні, корпоративній культурі, інформаційній системі, кодексі споживання.

Згідно із запропонованим підходом, у посткоронавірусному відновленні бізнес-активності мікропідприємства сфери гостинності велике значення має мобілізація внутрішнього потенціалу за певними компонентами (табл. 4).

Також $є$ доцільним для мобілізації внутрішнього потенціалу компанії впровадження процесного підходу в систему іiі управління, що грунтується на посткоронавірусній потребі забезпечення виживання, економічної безпеки, певного рівня конкурентоспроможності, скорочення часу трансформації ідей до нових вимог ринку, набуття модернізованих компетентностей персоналом, зміцнення позицій у сфері гостинності певного вітчизняного регіону.

Висновки. Сьогодні вітчизняні мікропідприємства сфери гостинності переживають час величезних мате-

Таблиця 4

Мобілізація потенціалу мікропідприємства за компонентами профілю його внутрішнього середовища

\begin{tabular}{|l|l|}
\hline Компонента & \multicolumn{1}{|c|}{ Змістовна готовність до посткоронавірусної інноваційності } \\
\hline Виробництво & $\begin{array}{l}\text { технологія, техніка, вертикальна інтеграція, закупка, якість, запаси, ідеї, інновації, патенти, ліцензії, дослі- } \\
\text { дження, енергія, приміщення тощо }\end{array}$ \\
\hline Фінанси & $\begin{array}{l}\text { коротко- і довгостроковий капітал, гнучкість структури капіталу, облік, можливість зниження витрат, опо- } \\
\text { даткування, рівень тінізації тощо }\end{array}$ \\
\hline Маркетинг & $\begin{array}{l}\text { продукти, послуги, сервіси, частка ринку, просування, канали продажу, збут, імідж, репутація, товарорух, } \\
\text { комунікації, клієнти, споживачі тощо }\end{array}$ \\
\hline Персонал & $\begin{array}{l}\text { управлінські кадри, еталон праці, мораль, плинність, компетентності, кваліфікація, мотивація, стимулювання, } \\
\text { дохід, кадрова політика тощо }\end{array}$ \\
\hline Менеджмент & $\begin{array}{l}\text { бізнес-мета, цінності, структура, організаційна культура, корпоративна етика, стратегічне планування, синер- } \\
\text { гія, внутрішні комунікації тощо }\end{array}$ \\
\hline
\end{tabular}


ріальних труднощів. Парадокс кризового періоду полягає у тому, що в умовах COVID-19 ведеться інтенсивна робота на рівні мікрокомпаній і підприємницьких структур із розроблення адаптивного механізму посткоронавірусного відновлення їхньої бізнес-активності. Однією з головних умов забезпечення конкурентоспроможності регіональної сфери гостинності у посткоронавірусному просторі автори вважають прийняття екстрених заходів зі збереження економічного потенціалу мікропідприємств, розвитку їхнього інтелектуального потенціалу, підприємницького духу й культури. Також украй важливою є роль інформатизації бізнес-процесів в ефективному функціонуванні мікропідприємства. Корисною допомогою мікробізнесу має стати успішний досвід трансформації та пристосування до нових глобальних умов мікрофірм з інших локацій, туристичних дестинацій, регіонів та країн. Подальші розвідки мають стати цікавими та корисними у напрямі розроблення посткоронавірусних пріоритетів трансформації цифрового бізнесу компаній.

\section{Список літератури:}

1. Державна служба статистики України. URL: http://www.ukrstat.gov.ua/ (дата звернення: 22.05.2021).

2. Корнієнко О., Кукліна Т. Міжнародний готельний бізнес: проблеми та перспективи. Інфраструктура ринку. 2019. № 31. URL: http://www.market-infr.od.ua/journals/2019/31_2019_ukr/6.pdf.

3. Кифяк В.Ф. Стратегія розвитку територіальних рекреаційних систем: теорія, методологія, практика : монографія. Київ ; Чернівці : Книги-XXI, 2010.

4. Tsviliy S., Vasylychev D., Gurova D. Improvement of the qualification of small \& micro-enterprise staff in the crisis conditions of business transformation. Економічний вісник ДВНЗ «УДХТУ». 2020. № 1(11)/20. С. 50-60.

5. Tsviliy S., Vasylychev D,. Gurova D. Innovative potential of the tourist territory in the strategy of sustainable development of the domestic region. Trends, prospect and challenges of sustainable tourism development : монографія. Львів : Львівський торговельно-еконон. університет, 2020. С. 51-66.

6. Індустрія гостинності в Україні: стан і тенденції розвитку : колективна монографія / за ред. В. Зайцевої. Запоріжжя : Просвіта, 2017. $240 \mathrm{c}$.

7. Стратегічне управління готельними підприємствами в умовах глобалізації : колективна монографія / ред. В. Зайцевої. Запоріжжя : ЗНТУ, 2018. 120 с.

8. Zhuravlova S. Development of ecological competence in modern specialists. XIX International Multidisciplinary Scientific GeoConference SGEM (2019, 28.06-7.07). 2019. URL: https://www.iaeg.info/event/xix-international-multidisciplinary-scientific-geoconference-sgem-2019/ (дата звернення: 21.05.2021).

\section{References:}

1. Derzhavna sluzhba statystyky Ukrayiny [State Statistics Service of Ukraine]. Available at: http://www.ukrstat.gov.ua. (in Ukrainian)

2. Korniienko O., Kuklina T. (2019) Mizhnarodnyi hotelnyi biznes: problemy ta perspektyvy [International hotel business: problems \& prospects]. Infrastruktura rynku (electronic journal), no. 31, pp. 27-30. Available at: http://www.market-infr.od.ua/ journals/2019/31_2019_ukr/6.pdf (accessed 10 February 2021).

3. Kyfiak V.F. (2010) Stratehiia rozvytku terytorialnykh rekreatsiinykh system: teoriia, metodolohiia, praktyka: monohrafiia [Strategy of development of territorial recreational systems: theory, methodology, practice: monograph]. Kyiv; Chernivtsi: Knyhy-KHKHI. (in Ukrainian)

4. Tsviliy S., Vasylychev D., Gurova D. (2020) Improvement of the qualification of small\& micro-enterprise staff in the crisis conditions of business transformation. Ekonomichnyy visnyk UDKHTU, no. 1(11)/20, pp. 50-60. (in English)

5. Tsviliy S., Vasylychev D,. Gurova D. (2020) Innovative potential of the tourist territory in the strategy of sustainable development of the domestic region. Trends, prospect and challenges of sustainable tourism development : monograph. Lviv: Lviv Trade and Economy University, pp. 51-66.

6. Zaitseva V.M. (ed.) (2017) Industriia hostynnosti v Ukraini: stan i tendentsii rozvytku [Hospitality industry in Ukraine: state and trends]. Zaporizhzhia: Prosvita. (in Ukrainian)

7. Zaitseva V.M. (ed.) (2018) Stratehichne upravlinnia hotelnymy pidpryiemstvamy v umovakh hlobalizatsiii [Strategic management of hotel enterprises in the context of globalization]. Zaporizhzhia: ZNTU. (in Ukrainian)

8. Zhuravlova S. (2019) Development of ecological competence in modern specialists. Proceedings from XIXInternational Multidisciplinary Scientific GeoConference SGEM 2019. Available at: https://www.iaeg.info/event/xix-international-multidisciplinary-scientific-geoconference-sgem-2019.

\section{ПОСТКОРОНАВИРУСНОЕ ВОССТАНОВЛЕНИЕ БИЗНЕС-АКТИВНОСТИ МИКРОПРЕДПРИЯТИЙ СФЕРЫ ГОСТЕПРИИМСТВА РЕГИОНА}

В статье изучены перспективы посткоронавирусного восстановления бизнес-активности отечественных микрокомпаний сферы гостеприимства региона. Вылелен ряд факторов, которые оказывают негативное влияние на бизнес региональной сферы гостеприимства. Проведен анализ опыта функционирования микропредприя- 
тий в условиях COVID-19. Представлена структура микробизнеса Запорожской области по видам экономической деятельности и проведен ее анализ за 2015-2019 г2. Сгруппированы микропредприятия по интегрированности в сферу гостеприимства региона. Разработаны рекомендации по выбору направления посткоронавирусного восстановления бизнес-активности отечественных компаний микробизнеса региона, которое предусматривает инновационное развитие на основе применения современного клиентоориентированного подхода.

Ключевые слова: бизнес, гостеприимство, компания, инновация, регион.

\section{POSTCORONAVIRUS RESTORATION OF BUSINESS ACTIVITY OF MICRO-ENTERPRISES IN THE REGION'S HOSPITALITY}

The article considers the theoretical principles and practical aspects of postcoronavirus recovery of business activity of domestic micro-companies in the hospitality region. The essential characteristics of the hospitality industry are determined on the basis of generalization of domestic and foreign experience. The modern realities of the hospitality sphere of the region are studied. A number of factors that have a negative impact on the microbusiness of the regional hospitality sector have been identified. The analysis of experience of functioning of microenterprises in the conditions of action of factors of pandemic COVID-19 is carried out. The structure of microbusiness of Zaporizhzhia region by types of economic activity is presented and its analysis for 2015-2019 is carried out. The grouping of micro-enterprises in terms of their integration into the sphere of hospitality of the region on the basis of their division by types of economic activity is made. The opinion of the owners of micro-enterprises with a high degree of integration into the hospitality sector of Zaporizhia region regarding the prospects of rapid recovery of business activity was studied and a fragment of the SWOT-analysis matrix was compiled based on the results of the questionnaire. Effective recommendations for the selection of a vector of postcoronavirus recovery of business activity of domestic micro-companies in the region, which provides for innovative development on the basis of a customer-oriented approach, have been developed. The substantial readiness of the microenterprise for postcoronavirus innovation is structured on the basis of mobilization of its potential according to the components of the profile of the internal environment: production, finance, marketing, personnel, management. It is concluded that the priority condition for ensuring the competitiveness of the regional hospitality sector in the postcoronavirus space is to take emergency measures to preserve the economic potential of micro-enterprises, development of their intellectual potential, entrepreneurial spirit and culture.

Key words: business, hospitality, company, innovation, region. 